\title{
ANTIDIABETES ACTIVITIES EXTRACT HEXANE FROM THE PEELS OF ARTOCARPUS CAMANSI BLANCO FRUIT
}

\author{
ROSNANI NASUTION ${ }^{1}{ }^{*}$, CHAIRANI NUR FITRAH ${ }^{1}$, HIRA HELWATI ${ }^{1}$, MURNIANA $^{1}$, BASTIAN ARIFIN ${ }^{2}$, \\ CUTCHAMZURNI ${ }^{3}$, YOSE RIZAL ${ }^{4}$, MARIANNE ${ }^{5}$
}

\begin{abstract}
${ }^{1}$ Department of Chemistry, Faculty of Mathematics and Natural Sciences, Syiah Kuala University, Banda Aceh, 23111, Indonesia. ${ }^{2}$ Department of Chemical Engineering, Faculty of Engineering, Syiah Kuala University, Banda Aceh, 23111, Indonesia. ${ }^{3}$ Department of Plant Protection, Faculty of Agriculture, Syiah Kuala University, Banda Aceh, 23111, Indonesia. ${ }^{4}$ Department of Computer System, Faculty of Computer Science, Pembangunan Panca Budi University, Medan, Indonesia. ${ }^{5}$ Department of Pharmacology, Faculty of Pharmacy, University of Sumatera Utara, Medan, Indonesia, 20155. Email: rosnani@unsyiah.ac.id
\end{abstract}

Received: 13 October 2017, Revised and Accepted: 14 February 2018

ABSTRACT

Objective: The purpose of this research is to know the chemical compound from the n-hexane extract of Kulu (Artocarpus camansi Blanco) fruit peels and to know its antidiabetes activity against male Swiss Webster mice.

Methods: Samples were macerated with n-hexane solvent, then extract $n$-hexane were obtained, the extract obtained was characterized by gas chromatography-mass spectrometry and separated by column chromatography. The results obtained were tested by antidiabetes action with glucose tolerance method.

Results: Anti-diabetic activity test result showed that the most active sample to decrease the blood glucose of mice was n-hexane crude extract, at minute $90^{\text {th }}$, activeness was $65.59 \%$, compared to glibenclamide, then group of fraction A, at minute $90^{\text {th }}$, activeness $65.58 \%$ compared glibenclamide, whereas isolate D1, its activity is $60.11 \%$ and $60.12 \%$, at minute $60^{\text {th }}$ and 90 min compared to glibenclamide. Concentrated extracts were characterized by GC-MS, shows the major compounds are hexadecanoic acid methyl ester (30.14\%), 9,12-octadecadienoyl chloride, (Z, Z) - (8.44\%) and 9-octadecenoic acid, methyl ester (30,91\%) also were obtained a compound like an $\beta$-amyrin acetate.

Conclusion: The most active sample to decrease the blood glucose of mice was n-hexane crude extract, and the major compounds are hexadecanoic acid methyl ester (30.14\%), 9,12-octadecadienoyl chloride, (Z, Z) - (8.44\%) and 9-octadecenoic acid, methyl ester (30.91\%).

Keywords: n-hexane extract, Artocarpus camansi, Antidiabetic, Glucose tolerance.

(c) 2018 The Authors. Published by Innovare Academic Sciences Pvt Ltd. This is an open access article under the CC BY license (http://creativecommons. org/licenses/by/4. 0/) DOI: http://dx.doi.org/10.22159/ajpcr.2018.v11s1.26554

\section{INTRODUCTION}

Along with the study of the antidiabetic activity of ethyl acetate extract of Artocarpus camansi Blanco fruit, in Swiss Webster mice, there were also studies of the hexane extract with appropriate methods and bioindicators. Species in the Artocarpus genus, which belong to the Moraceae family, have been widely used as medicines and nutritious foods and are often used as a complement to cuisine [1], one of which is the Kulu plant (A. camansi Blanco).

Previous research which has been done showed that testing of hexane extract from A. camansi Blanco leaves to mice showed a decrease in blood glucose levels of mice [2]. The $\beta$-sitosterol propionate compound in the extract shows the ability to reduce blood glucose levels of mice, besides that, the extract ethyl acetate of bark contains $\beta$-amyrin compounds which also have the same activity [3], but research on the fruit is relatively small.

Based on this above, it is strategic to do research on the A. camansi Blanco fruit peel, that is suspected to have the same content and the same properties as parts of plants that have been reported or more unique.

\section{METHODS}

Plant materials and bioindicator

The sample used in this research is A. camansi Blanco fruit peel collected from around Aceh Besar, Aceh. Bioindicator used in this research is male Swiss Webster mice.

\section{Spectroscopic investigation}

Mass spectra were measured using a Shimadzu GC-MS QP 2010 Ultra. Column chromatography was performed on silica gel 60 (70-230 mesh Merck). TLC analysis was carried out using precoated silica gel plates (Merck).

\section{Testing phytochemicals}

Phytochemical methods, Simplified Determination Methods to Analyze plant [4].

\section{Extraction and isolation}

The old A. camansi Blanco fruits are skinned, then the peels are dried for 1 to 2 weeks, and mashed, and weighed as much as $2.2 \mathrm{~kg}$. The sample was macerated with $n$-hexane solvent for $3 \times 24 \mathrm{~h}$, then filtered and taken filtrate, then concentrated on a rotary evaporator and obtained n-hexane extract of $104.6 \mathrm{~g}$ (4.75\%). The n-hexane extract was further tested phytochemically, characterized by GC-MS and tested antidiabetic activity using the glucose tolerance method.

\section{Fractionation extract $\mathrm{n}$-hexane of fruit peel $\boldsymbol{A}$. camansi}

A total of $30 \mathrm{~g}$ of concentrated $\mathrm{n}$-hexane extract was fractionated using gravity column chromatography. The eluent system used was n-hexane:ethyl acetate (elution gradient) with a ratio of $100,97.5: 2.5$, $95: 5,90: 10$, and 80:20. The results of the separation were obtained 113 fractions, and grouped into 4 fraction groups: A (1-18, as much as $0.3 \mathrm{~g}$, solid/white); B (19-32, as much as 20 g, solid/white), C (33-98, as much as $1.5 \mathrm{~g}$, solid/green), and D (99-112, as much as $0.8 \mathrm{~g}$, gel/yellow). The four groups of fractions were then tested for their antidiabetic activity; the observation result showed that group of the fraction of $\mathrm{D}$ is the 
active decreased the blood glucose level of the mice so that the fraction group D, was re-chromatograph. The fractional D group as much as 0.8 g, was re-chromatographed and resulted in a relatively pure fraction of 6 and 7, then the fraction 6 and 7 were combined and obtained as much as $0.3 \mathrm{~g}$ (D1) and rechromatographed, yielded 17 fractions. The fractions 2 and 3 are thought to be purely merged (D1), then tested with three eluent n-hexane systems:ethyl acetate (7:3), n-hexane:ethyl acetate (6:4) and n-hexane:chloroform (5:5), shows the isolate is clean, then the compound D1 is tested antidiabetic activity.

\section{Glucose tolerance test}

Before use, the mice were acclimatized for 7 days under laboratory conditions and received adequate food and beverages. After 7 days, healthy mice were selected, characterized by stable or increased weight and did not show any abnormal behavior. Mice were divided into 7 groups, each group of 3 mice [5]. Group I, control, given CMC-Na (1\%), Group II, the standard diabetes drug that is glibenclamide, given at a dose of $0.45 \mathrm{mg} / \mathrm{kg} \mathrm{BW}$. Group III-VII given test extract from A. camansi Blanco plant fruit with a dose of $50 \mathrm{mg} / \mathrm{kg} \mathrm{BW}$ [6]. After being fasted for $20-24 \mathrm{~h}$, the weight of the mice is weighed; fasting blood glucose level is measured, then treated as above. After $30 \mathrm{~min}$, all mice were given oral glucose $3 \mathrm{~g} / \mathrm{kg} \mathrm{BW}$. Blood glucose levels were then measured at 30, 60, 90 , and $120 \mathrm{~min}$.

\section{Blood samples}

Mice were put in a box modification (restrainer), tail cleaned with wet cotton so that the dirt is gone, then smeared with alcohol $70 \% \mathrm{v} / \mathrm{v}$. Blood was drawn through the lateral tail vein, which was cut aseptically approximately 1-2 mm from the tip of the tail without anesthesia, blood droplets first removed, then the next drop of blood dripped on the strip One Touch Horizon.

\section{Statistical analysis}

Statistical analysis was performed using Statistical Product and Service Solution (SPSS) Program. Analysis of variance was performed using ANOVA one-way and $(\mathrm{p}<0.05)$ using Tukey [7].

\section{RESULTS AND DISCUSSION}

Phytochemical test of fruit peel of $A$. camansi Blanco

The results of the phytochemical analysis showed that fruit peel of A. camansi, contains steroids and terpenoids, this is indicated by the formation of green and red when added Liebermann-Burchard reagent.

\section{Characterization of $\mathrm{n}$-hexane extract of $\boldsymbol{A}$. camansi fruit peel with} GC-MS

The A. camansi fruit n-hexane extract was characterized by GC-MS, the chromatogram of n-hexane extract in Fig. 1.

Based on Fig 1, there are 38 compounds contained in n-hexane extract of fruit peel A. camansi Blanco, the compounds can be seen in Table 1.

According to Table 1 , it is known that there are 38 compounds contained in the n-hexane extract $A$. camansi Blanco. There are three major compounds in the n-hexane extract of $A$. camansi Blanco those are, hexadecanoic acid, methyl ester (30.14\%); 9.12-octadecadienoyl chloride, (Z, Z) - (8.44\%) and 9-octadecenoic acid, methyl ester (30.91\%). These three compounds belong to a straight chain compound (aliphatic). In the chromatogram, hexane extract of $A$. camansi Blanco peel, there are two peaks with retention times of 22,892 and 23.296 which are owned by hexadecanoic acid methyl ester compounds. Hexadecanoic acid methyl ester known as methyl palmitate is a natural endogenous fatty acid. The hexadecanoic acid methyl ester is a palmitic acid group compound that binds a methyl group with a molecular weight of $270 \mathrm{~g} / \mathrm{mol}$. Palmitic acid is a saturated fatty acid composed of 16 carbon atoms with the formula $\mathrm{CH}_{3}\left(\mathrm{CH}_{2}\right)_{14} \mathrm{COOH}$ [8]. Palmitic acid is present in the form of triglycerides in vegetable oils such as coconut oil, palm oil, palm kernel oil, avocado oil, coconut oil, cottonseed oil, soybean oil, sunflower oil, and others. Hexadecanoic Acid compounds have antioxidant activity and decreased cholesterol levels [9].
On a chromatogram with a retention time of 25,663 indicates a compound of a molecule weight (m/e) 294. Based on library data indicate the presence of linoleic acid group compounds. This compound is thought to be a compound of 9,12-octadecadienoyl chloride, (Z, Z) - (similarity 93\% on MS library). These compounds have an activity to reduce gastric secretion (antisecretory), antituberculosis, anticholinergics, and as contraceptives [9]

In chromatograms with retention time 26,523 showed compounds with molecular weight (m/e) 264. Based on library research data indicate the presence of 9-octadecenoic acid, methyl ester, (E) - (CAS) Methyl Elaidate. Compound 9-octadecenoic acid methyl ester, (E) - has an activity of decreasing cholesterol, antiarthritis, antihistamine, insecticide, and anti-acne [9].

Of the nine compounds detected in GC-MS suspected triterpenoid compounds, one of them is on chromatogram with the retention time of 49.095 with the area (0.08). Based on the fragmentation pattern it is suspected that a compound is a group of amyrin compounds. Based on the typical MS on the chromatogram are: 468, 426, 218 (100), 203 (44), and 189 (17) [10]. Fragment pattern is similar to the $\beta$-amyrin acetate compound. Chromatogram pattern can be seen in Fig. 2.

The presence of this $\beta$-amyrin acetate compound is also reinforced by previous research that in the ethyl acetate extract of $A$. camansi Blanco bark contains a $\beta$-amyrin compound which can decrease blood glucose level in mice [3].

Test of antidiabetic n-hexane extract/group of fraction A. camansi Blanco The antidiabetic activity test was performed using glucose tolerance method in Swiss Webster male mice, the result of measurement of decrease/ increase of blood glucose of mice after the treatment is shown in Fig. 3.

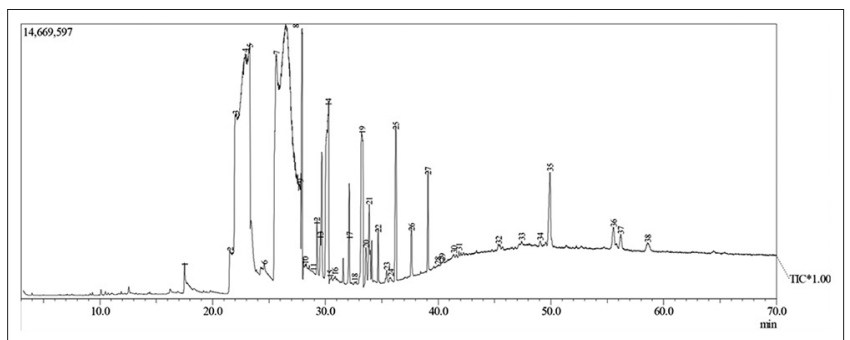

Fig. 1: Chromatogram of gas chromatography characterization of n-hexane extract of fruit peel Artocarpus camansi Blanco

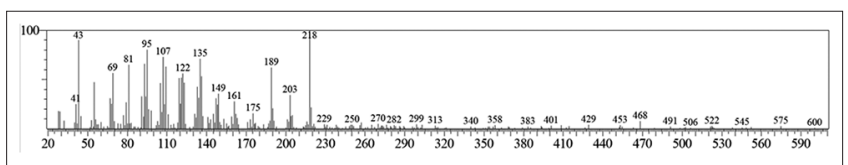

Fig. 2: The mass spectrum of the compound with a retention time of 49,095

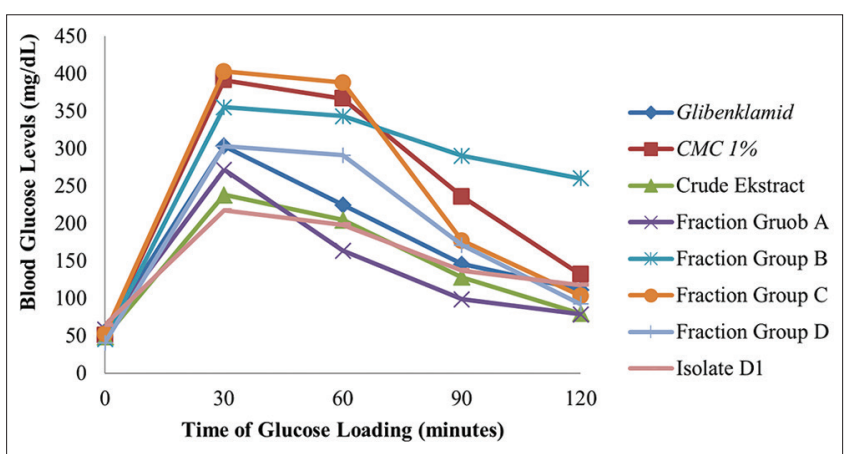

Fig. 3: Graphs decrease/increase in blood glucose levels mice with given, hexane extract, fractions group A-D, and isolate D1 
Table 1: The compounds contained in n-hexane extracts of fruit peel of $A$. camansi Blanco

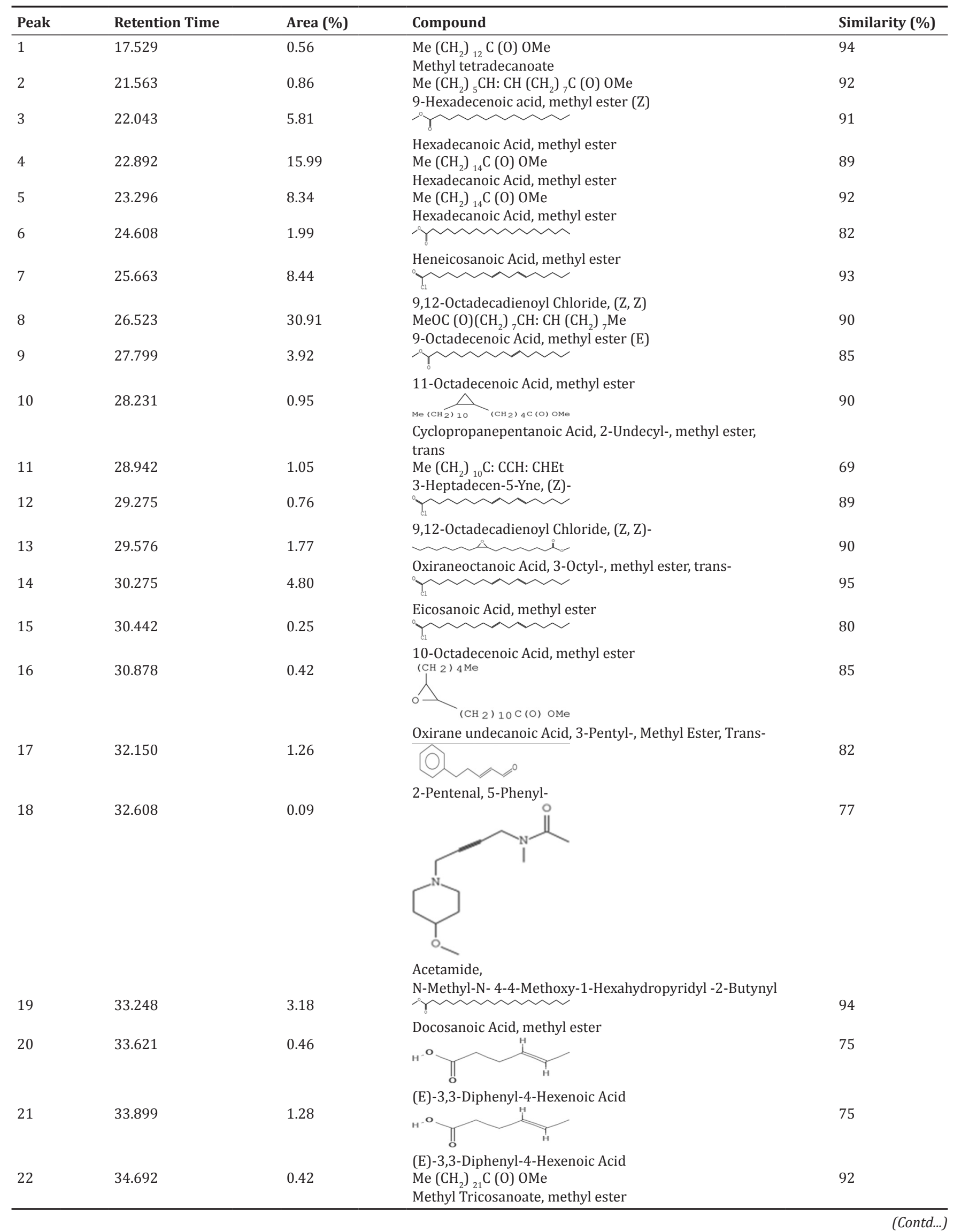


Table 1: (Continued)

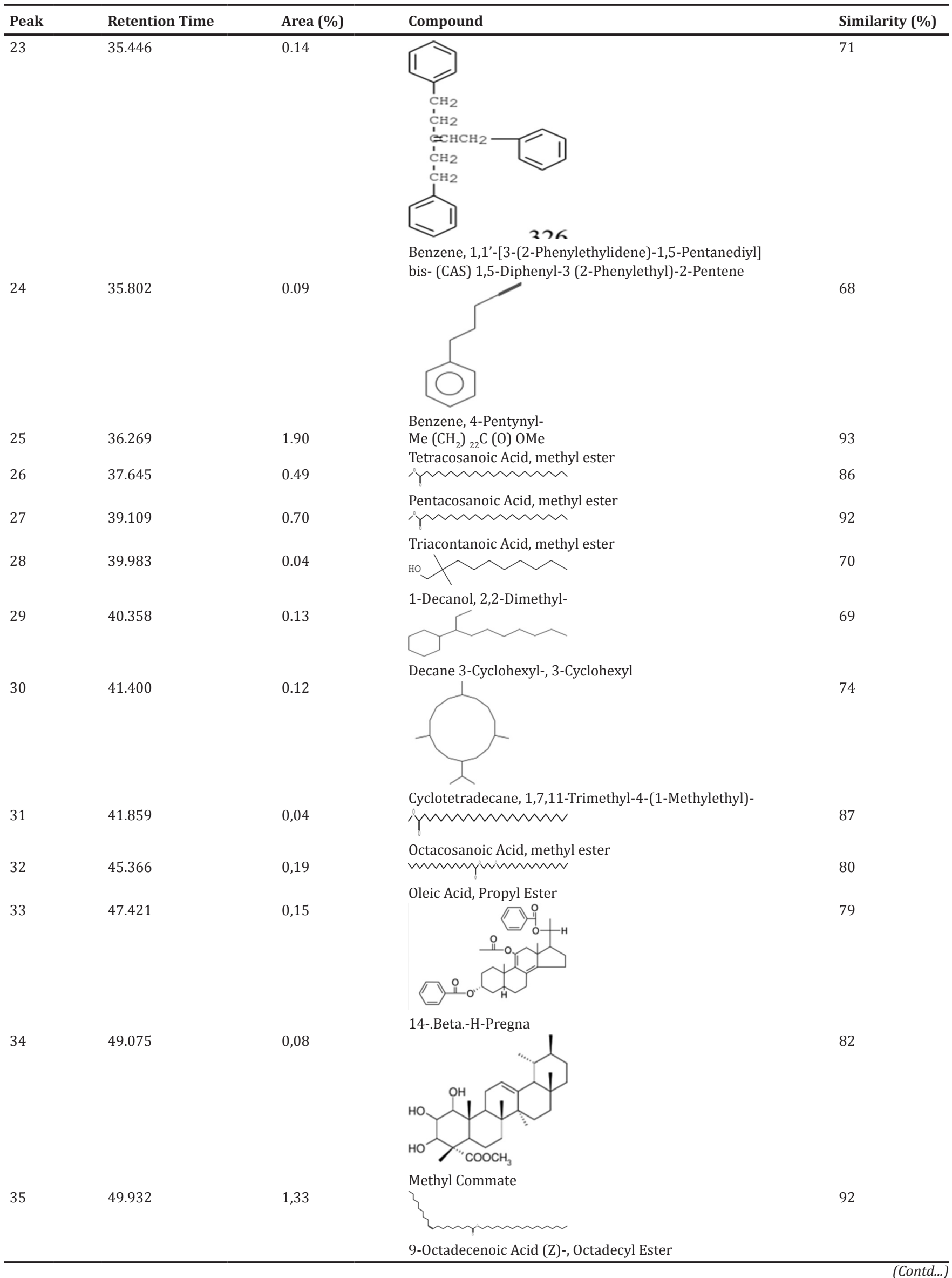


Table 1: (Continued)

\begin{tabular}{lllll}
\hline Peak & Retention Time & Area (\%) & Compound & Similarity (\%) \\
\hline 36 & 55.562 & 0,53 & 0,28 & 90 \\
37 & 56.216 & 0,28 -Hexadecenoic Acid, 9-Octadecenyl Ester, (Z, Z) & 90 \\
38 & 58.610 & 0,30 & 9-Octadecenoic Acid, 9-Octadecenyl Ester, (Z, Z) & (CH 2) 3S (0) Me \\
& & &
\end{tabular}

A. camansi: Artocarpus camansi

Measurement of blood glucose of mice given hexane extract increased blood glucose level in $30 \mathrm{~min}$ to $238.33 \mathrm{mg} / \mathrm{dL}$, from the initial blood glucose level $48.66 \mathrm{mg} / \mathrm{dL}$, and then, blood glucose level decreased at $60^{\text {th }} \mathrm{min}, 90^{\text {th }}$ and $120^{\text {th }}$, respectively, $205 \mathrm{mg} / \mathrm{dL}, 128.33 \mathrm{mg} / \mathrm{dL}$, and $80 \mathrm{mg} / \mathrm{dL}$.

The mice given the group of fraction A experienced an increase in blood glucose in the $30^{\text {th }} \mathrm{min}$ to $272 \mathrm{mg} / \mathrm{dL}$ from the initial blood glucose $58.33 \mathrm{mg} / \mathrm{dL}$, then decreased at $60^{\text {th }}, 90^{\text {th }}$, and $120^{\text {th }} \mathrm{min}$, i.e., $163.67 \mathrm{mg} / \mathrm{dL}, 99 \mathrm{mg} / \mathrm{dL}$, and $78.67 \mathrm{mg} / \mathrm{dL}$.

The mice given the fraction group of B experienced an increase in blood glucose in the $30^{\text {th }} \mathrm{min}$ to $355.33 \mathrm{mg} / \mathrm{dL}$ from the initial blood glucose of $46 \mathrm{mg} / \mathrm{dL}$, then decreased at $60^{\text {th }}, 90^{\text {th }}$, and $120^{\text {th }}$ min, respectively: $343.33 \mathrm{mg} / \mathrm{dL}, 290.67 \mathrm{mg} / \mathrm{dL}$, and $260.33 \mathrm{mg} / \mathrm{dL}$. The mice given the fraction group of $\mathrm{C}$ experienced an increase in blood glucose in the $30^{\text {th }} \mathrm{min}$ to $403 \mathrm{mg} / \mathrm{dL}$ from initial blood glucose $53 \mathrm{mg} / \mathrm{dL}$, then decreased at $60^{\text {th }}, 90^{\text {th }}$, and $120^{\text {th }} \mathrm{min}$, respectively: $388.33 \mathrm{mg} / \mathrm{dL}$, $177.33 \mathrm{mg} / \mathrm{dL}$, and $103.67 \mathrm{mg} / \mathrm{dL}$.

The mice given the fraction group of $\mathrm{D}$ experienced an increase in blood glucose in the $30^{\text {th }} \mathrm{min}$ to $303.33 \mathrm{mg} / \mathrm{dL}$ from the initial blood glucose of $41 \mathrm{mg} / \mathrm{dL}$ mice then decreased at $60^{\text {th }}, 90^{\text {th }}$, and $120^{\text {th }}$ min, respectively: $291.33 \mathrm{mg} / \mathrm{dL}, 171.33 \mathrm{mg} / \mathrm{dL}$, and $92.67 \mathrm{mg} / \mathrm{dL}$.

The mice given pure isolates $\mathrm{D} 1_{1}$ increased blood glucose at minute $30^{\text {th }}$ to $217.33 \mathrm{mg} / \mathrm{dL}$ from initial blood glucose of $64.67 \mathrm{mg} / \mathrm{dL}$ mice then decreased at $60^{\text {th }}, 90^{\text {th }}$, and $120^{\text {th }} \mathrm{min}$, respectively: $198.67 \mathrm{mg} / \mathrm{dL}$, $137.33 \mathrm{mg} / \mathrm{dL}$, and $118 \mathrm{mg} / \mathrm{dL}$.

Mice as a positive control given glibenclamide, in the $30^{\text {th }} \mathrm{min}$ increased blood glucose to $303.5 \mathrm{mg} / \mathrm{dL}$ from the initial glucose level of $56.25 \mathrm{mg} / \mathrm{dL}$, then decreased at $60^{\text {th }}, 90^{\text {th }}$, and $120^{\text {th }}$ min, respectively: $225 \mathrm{mg} / \mathrm{dL}, 146 \mathrm{mg} / \mathrm{dL}$, and $111.75 \mathrm{mg} / \mathrm{dL}$.

Mice as a negative control given only $1 \% \mathrm{CMC}$, the initial glucose level of $51.33 \mathrm{mg} / \mathrm{dL}$, then in the $30^{\text {th }} \mathrm{min}$ increased to $391.67 \mathrm{mg} / \mathrm{dL}$. In the $60^{\text {th }} \mathrm{min}, 90^{\text {th }}$ and $120^{\text {th }}$ decreased, respectively: Amounted to $367 \mathrm{mg} / \mathrm{dL}, 236.33 \mathrm{mg} / \mathrm{dL}$, and $132.33 \mathrm{mg} / \mathrm{dL}$.

To see the activity of lowering blood sugar in mice by reducing blood glucose levels of mice on negative control with blood glucose levels of mice given test preparation (crude extract, fraction group A, fraction group B, Fraction C group, Fraction D group, and Isolate D1 $1_{1}$. The reduction results are shown in Fig. 4 below.

Measurement of blood glucose mice given crude extract at minute $30^{\text {th }}$ can decrease blood glucose as much as $153.33 \mathrm{mg} / \mathrm{dL}$, in minutes $60^{\text {th }}, 90^{\text {th }}$, and $120^{\text {th }}$ decrease blood glucose of mice equal to $162 \mathrm{mg} / \mathrm{dL}$, $108 \mathrm{mg} / \mathrm{dL}$, and $52.33 \mathrm{mg} / \mathrm{dL}$.

The fraction group $\mathrm{A}$ in the $30^{\text {th }}$ min reduced blood glucose levels of mice by $119.33 \mathrm{mg} / \mathrm{dL}$ at $60^{\text {th }}, 90^{\text {th }}$, and $12^{\text {th }}$ min decreased blood glucose by $203,33 \mathrm{mg} / \mathrm{dL}, 137 \mathrm{mg} / \mathrm{dL}$, and $53.67 \mathrm{mg} / \mathrm{dL}$.

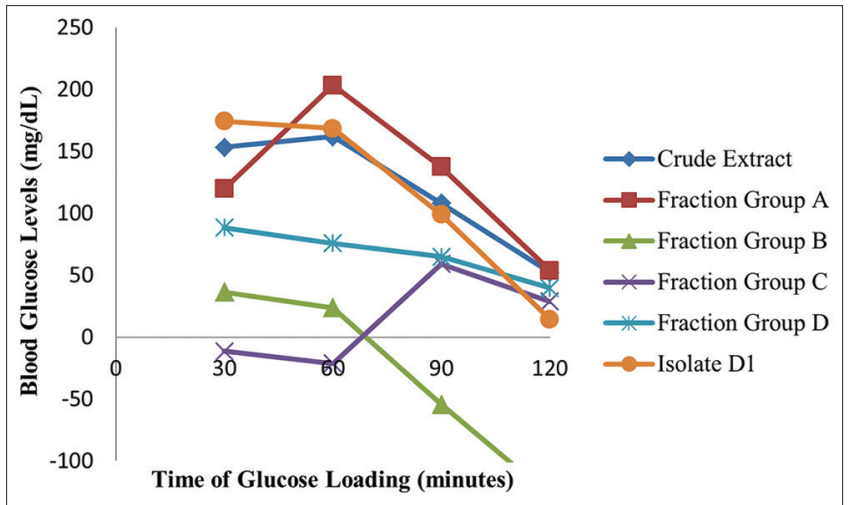

Fig. 4: Reduction of blood glucose levels of mice on negative control with blood glucose levels of mice given sample (crude extract, fraction group A-D, and Isolates D1 $)$

Mice were given a group of $\mathrm{B}$ fraction at minute $30^{\text {th }}$ and $60^{\text {th }}$ can decrease blood glucose of mice as much as, respectively: $36,33 \mathrm{mg} / \mathrm{dL}$ and $23,67 \mathrm{mg} / \mathrm{dL}$, while at minute $90^{\text {th }}$ and $120^{\text {th }}$ have an increase of blood glucose of mice ie $54.33 \mathrm{mg} / \mathrm{dL}$ and $128 \mathrm{mg} / \mathrm{dL}$.

Mice were given fraction group of $\mathrm{C}$ at minute $30^{\text {th }}$ and $60^{\text {th }}$ can increase blood glucose of mice $11.33 \mathrm{mg} / \mathrm{dL}$ and $21.33 \mathrm{mg} / \mathrm{dL}$, while at minute $90^{\text {th }}$ and $120^{\text {th }}$ can decrease blood glucose of mice by $59 \mathrm{mg} / \mathrm{dL}$ and $28.67 \mathrm{mg} / \mathrm{dL}$.

The mice given group fraction of $\mathrm{D}$ at minute $30^{\text {th }}$ can decrease the blood sugar of mice by $88.33 \mathrm{mg} / \mathrm{dL}$, and at minute $60^{\text {th }}, 90^{\text {th }}$, and $120^{\text {th }}$ can decrease the mice blood glucose of each: $75,67 \mathrm{mg} / \mathrm{dL}, 65 \mathrm{mg} / \mathrm{dL}$, and $39.67 \mathrm{mg} / \mathrm{dL}$.

The mice given pure isolate $\mathrm{D} 1_{1}$ in the $30^{\text {th }}$ min can decrease the blood glucose of mice by $174.33 \mathrm{mg} / \mathrm{dL}$, and in the $60^{\text {th }} \mathrm{min}, 90^{\text {th }}$, and $120^{\text {th }}$ can decrease the mice blood glucose by, respectively: $168.33 \mathrm{mg} / \mathrm{dL}, 99 \mathrm{mg} / \mathrm{dL}$, and $14.33 \mathrm{mg} / \mathrm{dL}$.

The statistical test was conducted by one-way ANOVA method with $95 \%$ confidence interval $(\mathrm{p}<0.05)$. Based on SPSS test result using oneway ANOVA method all test preparation has no significant difference with positive and negative control, it means that all compounds of its activity cannot be distinguished from negative blood glucose control. Furthermore, the activity of decreasing the blood sugar of each mouse of the test preparation compared with the activity of decreasing the blood sugar of mice given with glibenclamide (control positive), can be seen in Table 2.

Based on Table 2, the activity of hexane extract of $A$. camansi Blanco peel is moderate compared to glibenclamide, while the most active sample in the above table compared to positive control is crude 
Table 2: Comparison of the activity of each test preparation to positive control

\begin{tabular}{lllll}
\hline Test preparation & \multicolumn{3}{l}{$\begin{array}{l}\text { Time for measurement of blood glucose } \\
\text { mice (minute) }\end{array}$} \\
\cline { 2 - 5 } & $\mathbf{3 0 ( \% )}$ & $\mathbf{6 0}(\mathbf{\% )}$ & $\mathbf{9 0}(\%)$ & $\mathbf{1 2 0}(\mathbf{\% )}$ \\
\hline Crude extract & 38.85 & 57.85 & 65.59 & 48 \\
Fraction Group of A & 30.06 & 57.85 & 6558 & 49.23 \\
Fraction Group of B & 9.2 & 8.45 & -32.9 & 117 \\
Fraction Group of C & -2.87 & -7.61 & 35.85 & 26.29 \\
Faction Group of D & 22.38 & 27 & 39.47 & 36.38 \\
Isolates D1 & 44 & 60.11 & 60.12 & 13.11 \\
\hline
\end{tabular}

+ (no sign) Lowers blood sugar - Raise blood sugar

extract, at $90^{\text {th }} \mathrm{min}$, its activity is $65.59 \%$, compared to glibenclamide. Next fraction group A, at minute $90^{\text {th }}$, activeness $65.58 \%$ compared to glibenclamide. Isolates $\mathrm{D} 1_{1}$, its activity is $60.11 \%$; and $60.12 \%$ compared to glibenclamide at $60^{\text {th }}$ and $90^{\text {th }}$ min. Other test preparations have activity lower than 50\% compared to glibenclamide which means not active to lowering the blood sugar of mice. As a positive control for testing the hepatoprotective can be used catechin compounds [11].

\section{CONCLUSION}

The results of the phytochemical analysis showed that fruit peel of A. camansi Blanco, contains steroids and terpenoids, and characterization of n-hexane extract with GC-MS obtained by major compound, i.e., hexadecanoic acid methyl Ester (CAS) methyl palmitate (30.14\%), 9,12-octadecadienoyl chloride, (Z, Z) - (8,44\%) and 9-octadecenoic acid, and methyl ester (30.91\%). And based on Mass spectrometry, there is a compound that resembles its fragmentation with the $\beta$-amyrin acetate.

The most active sample to decrease the blood glucose of mice was n-hexane crude extract at $90^{\text {th }} \mathrm{min}$, its activity is $65.59 \%$, compared to glibenclamide.

\section{ACKNOWLEDGMENTS}

The authors are grateful to Syiah Kuala University, Ministry of Research, Technology, and Universities, Indonesia.

\section{REFERENCES}

1. Hari A, Revikumar KG, Divya D. Artocarpus: A review of its phytochemistry and pharmacology. J Pharm Search 2014;1:7-9.

2. Nasution R, Barus T, Nasution P, Saidi, N. Isolation and structure elucidation of steroid from leaves of Artocarpus camansi (Kulu) as antidiabetic. Int J PharmTech Res 2014;6:1279-85.

3. Nasution R, Marianne, Nur H. ß-Amyrin acetate of ethyl acetate extract of the bark plant Artocarpus camansi and its antidiabetic activity. Pharm Chem 2015;7:71-8.

4. Harborne JB. Phytochemical Methods-A Guide to Modern Techniques of Plant Analysis. $2^{\text {nd }}$ ed. London: Chapman and Hall; 1984. p. 4-16.

5. Triplitt CL, Reasner CA, Isley EL. Pharmacotheraphy A Pathophysiologic Approach. USA : McGraw-Hill Companies; 2005. p. 234-47.

6. Marianne, Yuandani, Nasution R. Antidiabetic activity from

ethanol extract of kluwih's leaf (Artocarpus camansi). J Natl 2011;11:64-5.

7. Santoso S. Complete Guide fo SPSS Version 20. Jakarta: PT Media Komputindo; 2012. Elex

8. Koram K, Addae M, Ocran J, Adu-Amankwah S, Rogers W, Nkrumah FK. Population based reference intervals for common blood haematological and biochemical parameters in the Akuapem north district. Ghana Med J 2007;41:160-6.

9. Kalaivani CS, Sathish SS, Janakiraman N, Johnson M. GC-MS studies on Andrographis paniculata (Burm.F) wall. ex Nees-A medicinally important plant. Int Med Arom Plants 2012;2:69-74.

10. Fingolo CE, Filho MD, Santos T, Kaplan MA. Triterpene esters: Natural products from Dorsteni arifolia (Moraceae). Molecules 2013;18:4247-56

11. Chrestella JM, Ginting AM, Dalimunthe A, Nasution R. Hepatoprotective activity combination of curanga Fel-Terrae Lour Leaves and curcuma Heyneana Valeton and Zijp rhizome in rat induced by combination of rifampisin and isoniazid. Int J Pharm Pharm Sci 2017;9:23-8 